\title{
Three-dimensional bio-printing
}

\author{
GU Qi ${ }^{1,2}$, HAO Jie ${ }^{1}$, LU YangJie ${ }^{1}$, WANG Liu ${ }^{1}$, WALLACE Gordon G. ${ }^{2^{*}} \&$ ZHOU Qi ${ }^{{ }^{*}}$ \\ ${ }^{1}$ State Key Laboratory of Reproductive Biology, Institute of Zoology, Chinese Academy of Sciences, Beijing 100101, China; \\ ${ }^{2}$ ARC Centre of Excellence for Electromaterials Science (ACES), Intelligent Polymer Research Institute, AIIM Facility, Innovation Campus, \\ University of Wollongong, NSW 2522, Australia
}

Received January 8, 2015; accepted March 8, 2015; published online April 15, 2015

\begin{abstract}
Three-dimensional (3D) printing technology has been widely used in various manufacturing operations including automotive, defence and space industries. 3D printing has the advantages of personalization, flexibility and high resolution, and is therefore becoming increasingly visible in the high-tech fields. Three-dimensional bio-printing technology also holds promise for future use in medical applications. At present 3D bio-printing is mainly used for simulating and reconstructing some hard tissues or for preparing drug-delivery systems in the medical area. The fabrication of 3D structures with living cells and bioactive moieties spatially distributed throughout will be realisable. Fabrication of complex tissues and organs is still at the exploratory stage. This review summarize the development of 3D bio-printing and its potential in medical applications, as well as discussing the current challenges faced by $3 \mathrm{D}$ bio-printing.
\end{abstract}

3D bio-printing, cell, function, fabrication

Citation: Gu Q, Hao J, Lu YJ, Wang L, Wallace GG, Zhou Q. Three-dimensional bio-printing. Sci China Life Sci, 2015, 58: 411-419, doi: 10.1007/s11427-015-4850-3

Three-dimensional (3D) printing, also called rapid prototyping (RP), can be used to model and fabricate a three-dimensional object layer by layer. This involves computer or software aided design (CAD) and the printer transferring the signals into actions to fabricate the desired items with inkjet materials. Three-dimensional printing emerged from stereolithography (SLA) [1]. With SLA materials are sensitive to light or laser undergoing photon initiated solidification. The whole model is accomplished after all layers are formed [2]. Other 3D printing technologies are now available, including fused deposition modelling (FDM), selective laser sintering (SLS), digital light processing (DLP), three-dimensional printing (3DP), laminated object manufacturing (LOM), and polyjet (Table 1). Whatever the technology is, the basic theory is that the object consists of finite layers, and the greater the numbers of layers, the higher the resolution required [3]. There are different

*Corresponding author (email: gwallace@uow.edu.au; zhouqi@ioz.ac.cn) methods to fix the layers, some materials can be melted and coagulated easily, some can be laser moulded, and some can be easily coagulated. A complete $3 \mathrm{D}$ printing system contains software, to design moulds and operate, and a printer, the main part of the system. The printer can achieve inkjet and fabrication [4-6]. In China, it has been reported that the house could be printed, so the time, cost and pollution would be reduced (http://www.theguardian.com/). Additionally, 3D printing technique has been used to print batteries to precisely control the morphology of electrodes and to improve the capacity of the battery (http://3dprint.com/). Compared to traditional fabrication technology, the advantage of $3 \mathrm{D}$ printing is high resolution and individuation and it has been widely used in various areas including consumer products, film making and games [7].

With the development of biomaterials and cell biology, bionic medicine and regenerative medicine are becoming important research fields with fast growth. Bionic bones and cochlear have come into the market already and bionic eyes 
Table 1 Types of 3D printing technology

\begin{tabular}{|c|c|c|c|}
\hline Names & Description & Materials & Ref. \\
\hline SLA & Stereolithography: light sensitive materials could be solidified to a thin layer. & Thermoplastics & [2] \\
\hline FDM & $\begin{array}{l}\text { Fused deposition modelling: a fundamental 3D printing technology and is used } \\
\text { extensively. }\end{array}$ & Plastics and some foods & [8] \\
\hline SLS & $\begin{array}{c}\text { Selective laser sintering: similar to SLA, but solidify materials with the aid of } \\
\text { infrared laser. }\end{array}$ & Plastics, wax, ceramic and metal materials & [9] \\
\hline DLP & $\begin{array}{l}\text { Digital light processing: similar to SLA, but is faster because of whole layer } \\
\text { fabrication after laser scanning. }\end{array}$ & Photopolymer & [10] \\
\hline LOM & Laminated object manufacturing: the materials are fused by heating roller. & Paper, ceramic and metal materials & [12] \\
\hline Polyjet & $\begin{array}{l}\text { Similar to SLA, many tips and ultraviolet lights work together. Inkjet and solid- } \\
\text { ification could be accomplished simultaneously with higher resolution. }\end{array}$ & Thermoplastics & [13] \\
\hline
\end{tabular}

and hearts are in development. 3D printing has been used in fabricating hard-tissues which suit the damaged sites individually. With the involvement of cells, more complex organ could be printed. Here we review the application of 3D printing in biological and medical fields, summarize printing strategies and analyze the current issues of 3D bio-printing. Finally, we discuss the challenges of 3D bio-printing for future research.

\section{3D bio-printing}

3D printing technology used in biomedical field is denoted $3 \mathrm{D}$ bio-printing and it has a great potential for future regenerative therapy. An ideal 3D bio-printing system is shown schematically in Figure 1. Firstly, accurate information of tissues and organs should be collected for designing the model. Secondly, the server should be able to transfer the information into electrical signal to control the printer to print the tissues, and the printer should be able to maintain the cell viability during the fabrication process (Figure 1B and C). Usually, a tissue is composed of many types of cells and the cells will be mixed with some substances to be better fused (Figure 1C) [14-16]. At present, some hard tissues can be fabricated with bionic materials by $3 \mathrm{D}$ printer [17], and have been used in clinical trials. A real complicated tissue cannot be constructed from 3D printer at the moment. In the future, 3D bio-printer could be used to print organs for repairing the damaged body part, and to simulate some functional tissues for research, therapy and drug screening. Furthermore, 3D bio-printing can be used for personalized therapy that could reduce the cost of therapy. Biocompatible and biodegradable materials can be combined with $3 \mathrm{D}$ bio-printing to reduce the incompatibilities caused by materials $[15,18]$. Therefore, 3D bio-printing will lead to a novel technology revolution.

\subsection{History of 3D bio-printing and types of 3D bio-printing technology}

$3 \mathrm{D}$ printing is being acknowledged by more and more people, and that in turn will promote the development of the technology. 3D printing can benefit the bio-therapy field as well. It has been reported that only $20 \%$ of patients who wait for organ donation for grafting therapy can have organs to transplant, and the other patients have to keep waiting or are treated by alternative and often less appropriate therapy (http://www.unos.org/index.php). The history of tissue and organ culture in vitro is nearly 30 years old [19]. Langer and Vacanti [20] invented the technology of combining cells and materials. Tissue engineered organs would be a source of organs for transplantation in the future, but at present there have been no acceptable artificial organs for clinical trial. There are some successful cases in skin allograft trials, and tissues simply constructed in vitro, such as bladder, myocardial membrane and trachea, have also been used clinically [21-24]. But these tissues are two-dimensional cell sheets rather than $3 \mathrm{D}$ structure of dermis or epidermis [25]. Current 3D tissue fabrications have been achieved by adding cells to the specially formatted scaffolds [26-29]. 3D scaffolds can provide extracellular matrix to improve cell growth and interactions. The bio-degradable and biocompatible solid freeform fabrication (SFF) scaffolds have been used in tissue fabrication in vitro. Some SFF scaffolds can be built up with the help of computers to improve their accuracy and personalization [30]. Fusion of materials and cells can produce simple 3D dermis-like tissues, which, however, are only used in animal models [27]. With advanced equipment and formulation protocols, some tissues containing vessels can now be fabricated [31].

$3 \mathrm{D}$ printing can do a better job than the above mentioned, with the printed-out scaffolds being able to accurately depict the complicated bio-tissues and the cells being planted on them after fabrication is completed. Cells and tissues can also be printed simultaneously after encapsulating cells in materials. 3D bio-printing is a super multi-discipline technology involving tissue biology, cell biology, computer technology, materials science and medical sciences. The printed organs should meet the requirements of all these disciplines. At present, there are four types of $3 \mathrm{D}$ bio-printing technology which are derived from basic 3D printing techniques for depositing cells: valve-based, direct inkjet, acoustic and laser-mediated (Figure 2).

A valve-based $3 \mathrm{D}$ bio-printer controls the droplets size 


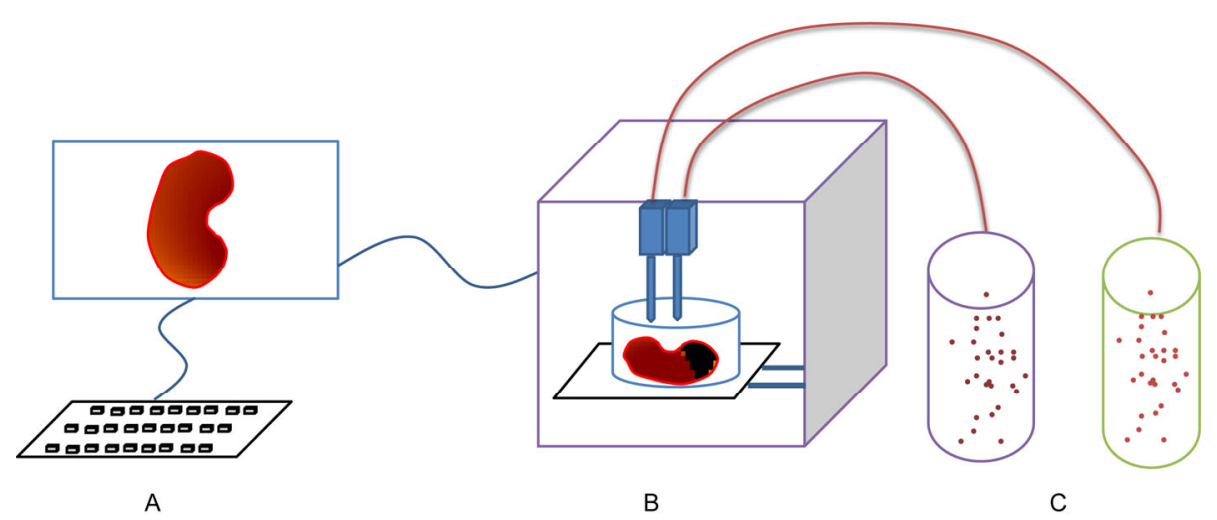

Figure 1 The diagram of ideal 3D bio-printing. A, Server, which is responsible for designing the model. B, 3D bio-printer, the main facility responsible for printing. C, The sources of different types of cells.

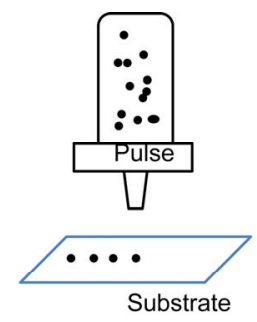

A
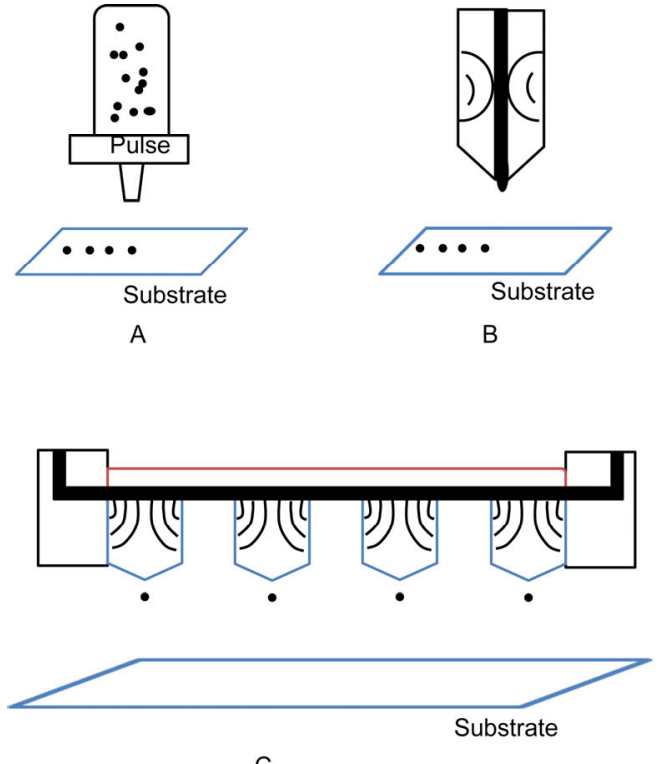

B

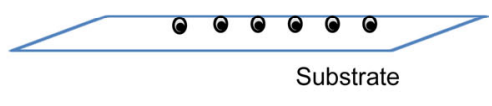

Figure 2 Four types of 3D bio-printing technology for depositing cells. A, Valve-controlled 3D bio-printing. B, Direct inkjet 3D bio-printing. C, Acoustic 3D bio-printing. D, Laser-mediated 3D bio-printing.

by modifying pulses (Figure 2A). Its resolution and throughput are both at moderate level. At present, it is mainly used in single cell sequencing and minute cell sample analysis [32].

Inkjet is a non-contact image reconstruction technology. The signals can reappear on the platform through ink droplets (Figure 2B). The technology has been widely used in electrical materials and integrated circuits [33]. Printing accuracy and specificity may be improved by manipulating ink droplets from microliter to picoliter. The technology has been applied to printing tissue-scaffolds and bio-materials. The difficulty is how to control the size and the flow continuity of the ink droplets [34,35]. Hydrodynamics needs to be considered here. Methods used by inkjet technology include piezoelectric ceramics and thermal conductivity. The technology can be used in high-throughput bio-printing but it is difficult to achieve control over single cells [36].
Laser-mediated bio-printing is a technology mediated by laser to position the cells of cell suspensions and tissue suspensions (Figure 2C). It is a commonly used 3D printing method and can be divided into the following sub-types: laser-guided bio-printing (LGB), biological laser processing (BIoLP), laser-induced forward transfer (LIFT), and matrix-assisted pulsed laser evaporation direct writing (MAPLEDW). LGB has low throughput but high resolution, and can control single cells. LIFT has higher throughput than LGB but a poor control of single cells. Heat generated by laser pulse is transmitted to the thin films that coat the cells and cut out cell droplets of particular sizes and shapes, which attach to the movable basement. The heat might affect the viability of cells [37].

There is no nozzle on the acoustic bio-printer (Figure 2C). The pressure of sound radiation can shake the cell ink and controls the droplet size by adjusting acoustic frequency and 
amplitude. It generates little energy thus does not harm cells [38]. At present, it has been used with many types of cells and cell suspensions, and has been used in some other fields such as manipulation of single cell DNA and RNA [39].

\subsection{Bio-active scaffolds from 3D printing}

Extracellular matrix (ECM) provides structural and biochemical support for cell growth and is composed of many types of proteins and glycans. The alteration of ECM would influence cell state and function [40,41]. With high resolution, 3D printing could be used to print scaffolds that mimic in vivo structure and environment of tissues, and there are many reports that scaffolds from 3D printing have been used in drug delivery, tissue engineering and cell viability tests $[14,15]$. Model fabrication is the first 3D printing application, with optimization of the technique and material modification, some bio-active hard tissues have been printed [42]. In 2012, the first clinical trial of 3D bio-printing was performed at a hospital in the Netherlands. A bionic jaw printed using 3D printer was transplanted into a patient (http://www.bbc.com/news/technology-16907104). Since then, more trials have been performed in Japan, Poland and some other countries (http://3dprint.com/19617/osteo3d3d-print-mouth/ and http://www.3ders.org/). The grafted materials can specifically interact with vocal organs without affecting the hearing and the vocality of patients [43].

To directly print the live tissues, many printed scaffolds were used for cell culture. Cells obtain higher viability and function when cultured on 3D scaffolds compared to two-dimensional environments [44,45]. Ploy caprolactone (PCL) scaffolds from printing have been used in culturing different types of cells, as shown in Table 2. However, this is just the combination of scaffolds with cells at the two-dimensional level, and is therefore called indirect 3D bio-printing. Actually, the interaction between cells and materials in the indirect 3D printing is still two-dimensional because only one side of the cell surround is scaffolds. Table 2 shows progress of application of 3D printing scaffolds on cell culture and another bio-printing called direct 3D bio-printing compared to indirect 3D bio-printing and the direct 3D bio-printing shows that the cells are encapsulated in materials and then are used as bio-ink.

\subsection{Cell 3D bio-printing}

There are more than 200 cell types in a human body, and these cells form different and complicated tissues and organs. That makes it difficult to replicate complex and functional 3D tissues and organs in vitro. 3D bio-printing may solve this problem. The ink droplets can deposit live cells and fabricate the tissues and organs as desired. Despite a promising future for organ transplantation, at the moment there has been no biologically active organ fabricated by 3D bio-printing. Each tissue and organ of the human body is sophisticated in construction, and the combinations of various types of cells require not only in vitro tests of viability and functionality but also in vivo tests of interactions with other tissues and organs. 3D printing has been widely used in the manufacturing industry. It has also been used in the bio-therapy field with hard and vessel-free structures. Gabor Forgacs and colleagues [46] printed short blood vessels and beating cardiac valves, demonstrating that cell-printing is possible. They later established a company named Organovo, dedicated to bio-printer development and marketing. Fibroblasts have been successfully printed by improving 3D printers [47]. Cell sources have been extended to adult stem cells and endothelial cells, and after printing, some cell-cell interactions can be observed. These pave the way for future 3D organ-printing [48].

When the cells are encapsulated into the materials and used for ink, we call this 3D bio-printing as direct 3D bio-printing as shown in Table 2. One disadvantage of cell encapsulated in materials is the loss of cell viability. Hydrogel is the first candidate for cell printing. To maintain cell viability and cell-cell interactions, some hydrogel materials can be added into the ink. Hydrogels can also work as substrates and scaffoldings [49]. Hydrogels have special chemical and physical properties, and can be degraded in vivo sometime after grafting. The initial materials used as scaffoldings were electrospun fibers, for substituting blood vessels [50]. Now collagen, ployanhydride and fibronectin have been widely used. It is still a hot field nowadays $[51,52]$. Below are some hydrogels having been used successfully in 2D fabrication via 3D printing technology and the functions of the fabricated products could also be detected: culture medium [53], agarose [54], alginate [55], collagen [56], matrigel [57-59], fibrin [60], k-70 series [61] and polyvinyl alcohol (PVA) [62]. After extruded from the printer tips, hydrogels would be polymerized by cross-linker [63]. It is a challenge to protect cells and to maintain the resolution during hydrogel's stabilization. Therefore, many new modified-hydrogels and methods are being explored [64-66].

Hydrogel is a type of polymer that could contain much water in the 3D structure. The mechanical properties and bio-properties of hydrogel need to be modified for printing and cell survival. At present, during printing and crosslinking there will be some cell death with a wide range $(\sim 2 \%-40 \%)$ because the cells are outside various natural environment $[65,67,68]$. There are chemical and physical ways to crosslink hydrogels. Gelatin is water soluble protein and has high biocompatibility [69]. With methacrylamide group modified, the gelatin (gelMA) could be cross-linked using ultraviolet rays [70]. The adding of hyaluronic acid (HA) improves gelMA printable properties [65]. Calcium could crosslink alginate and alginate-gelatin blends have been reported as potential materials for extrusion printing living cells $[71,72]$. Single cell printing has high resolution and could be used for cell patterning and material-cell blends precise control. Present technique "Block-Cell- 
Table 2 Examples of 3D bio-printing

\begin{tabular}{|c|c|c|c|c|}
\hline Types & Materials & Cells & Morphology & Ref. \\
\hline Indirect & PCL & Myoblast cell line $\mathrm{C} 2 \mathrm{C} 12$ & & [74] \\
\hline Indirect & $\begin{array}{l}\text { Calcium phosphate modified PCL } \\
\text { (PCL-CaP) treated with fibrinogen }\end{array}$ & $\begin{array}{l}\text { Mesenchymal stem cells } \\
\text { (MSCs) }\end{array}$ & & [75] \\
\hline Indirect & PCL & MSCs & & [76] \\
\hline Indirect & Glycerol with soy protein & MSCs & & [77] \\
\hline Indirect & PCL and alginate & $\begin{array}{l}\text { Osteoblast cells and chon- } \\
\text { drocyte }\end{array}$ & & [78] \\
\hline Indirect & Collagen and gelatin & There is no cell & & [79] \\
\hline Direct & Cell culture medium & $\begin{array}{c}\text { Mouse embryonic stem cells } \\
\text { (mESCs) }\end{array}$ & & [80] \\
\hline Direct & $\begin{array}{l}\text { Cells printed on PEUU immersed } \\
\text { in Matrigel }\end{array}$ & $\begin{array}{l}\text { Human umbilical vein endo- } \\
\text { thelial cells (hUVECs), MSCs }\end{array}$ & & [81] \\
\hline Direct & HA and gelMA & Chondrocyte & & [65] \\
\hline Direct & gelMA & Live cancer cell line, HepG2 & & [82] \\
\hline Direct & Single cell pattern & A few breast cancer cell lines & & [73] \\
\hline
\end{tabular}


Printing" even makes cell $100 \%$ living after printing [73].

\section{The future of 3D bio-printing}

It takes a long time and needs lots of cells when accomplishing an organ-printing [83]. During such a long period of time, how to ensure the accuracy of printing and the cell viability have become the crucial questions. The jet nozzle can be enveloped with aluminium alloy to prevent exposure to the radiations from laser [84]. At present, complicated tissue scaffoldings can be fabricated using hydrogels by laser-mediated 3D bio-printer and inkjet 3D bio-printer [79,85-88]. Yet in the process of 3D fusion, the use of high temperature and high pressure and some solvents may lead to the death of cells [89]. Three-dimensional tissue printed from a mixture of cells and hydrogels [78,90] possesses mechanical properties similar to natural structures but with limited cell expansion capabilities and function. This is one of the major limitations faced by $3 \mathrm{D}$ bio-printing at the moment [91]. Although many reports demonstrated the cells could be printed, there is still no report about the function of printed cells. At present, we could keep cells living in materials but we cannot direct the future state of cells [92]. Cell states are dependent on the varied substrates, many materials are developed to mimic the ECM [93-95], native tissue derived bio-ink is also proposed to simulated the in vivo environment [96]. Therefore, how to optimize the materials for cells' customization is one of future work.

Another issue of bio-printing is how to print organs containing blood vessels. Every organ needs the network of vessels and capillaries to supply oxygen, cytokines and nutrients, as well as to remove the wastes which are noxious to cells. It has been reported that cardiac muscle tissue containing vessel-like structure was obtained from endothelial cells through tissue culture [31]. Fabrication of functional 3D tissues containing blood vessels is still a great challenge faced by 3D bio-printing [97].

The key problem faced by 3D bio-printing is cell sources, as cells are the basic units of an organ. Stem cells may become the primary source for bio-printing. Stem cells have high viability and short cell cycle time, and can differentiate into other cell types in defined conditions. This may reduce the number of cells required in bio-printing, save printing time, and create conditions for printed organs to function. At present, initial trials have been performed in 3D bio-printing with stem cells. Embryonic stem cells were used in 3D printing to form embryoid bodies (EBs) [80]. Human mesenchymal stem cells (hMSCs) and human umbilical vein endothelial cells (hUVECs) were utilized to print fabricated patches to repair cardiac muscles [81]. However, there is still a long way to go in choosing the right stem cells for bio-printing the right organs.

Ideally 3D bio-printing involves in situ printing of cells at the site of injury. This requires rapid model construction, rapid printing and sufficient cell sources. Fulfilment of such requirements would lead to a revolution in regenerative medicine. For example, a quick repair of the skin wound with $3 \mathrm{D}$ bio-printing would increase the recovery rate and reduce permanent scarring.

In the quest for optimised 3D bio-printing of tissues and organs, how we characterize and evaluate the functions of the printed organs is also an area that requires development [98]. Relevant analyses shall include tests of cell viability, cell tracking, functional marker detection and animal model experiments. To accomplish 3D bio-printing of larger tissues structural scaffolds need to be utilised. Materials such as degradable poly caprolactone (PCL) have been used [74-76,78].

Establishment of safety evaluation systems for testing 3D bio-printed structures is another issue to be considered $[99,100]$. Appropriate regulatory frameworks are yet to be developed. 3D bio-printing is a new and complicated technology, and the process involves cell preparation, cell expansion, graft, materials and observation after grafting, and safety and efficiency evaluation.

In summary, 3D bio-printing holds a great promising future. Real clinical advances require parallel advance in many fields to occur.

This work was supported by the National Basic Research Program of China (2011CB965000) and Chinese Academy of Sciences Strategic Priority Research Program Grants (XDA01030506).

1 Hull, Charles W. Apparatus for production of three-dimensional objects by stereolithography. US Patent, 4575330, 1986-3-11

2 Melchels FP, Feijen J, Grijpma DW. A review on stereolithography and its applications in biomedical engineering. Biomaterials, 2010, 31: 6121-6130

3 Koch L, Gruene M, Unger C, Chichkov B. Laser assisted cell printing. Curr Pharm Biotechnol, 2013, 14: 91-97

4 Zuzak K, Cadeddu JA, Ufret-Vincenty R, Francis RP, Livingston E. Digital light processing hyperspectral imaging apparatus. US 08406859

5 Sun C, Fang N, Wu DM, Zhang X. Projection micro-stereolithography using digital micro-mirror dynamic mask. Sensor Actuat a-Phys, 2005, 121: 113-120

6 Bourell DL, Marcus HL, Barlow JW, Beaman JJ. Selective laser sintering of metals and ceramics. Int J Powder Metall, 1992, 28: 369-381

7 Ulbrich CBL, Zavaglia CAC, Neto PI, Oliveira MF, Silva JVL. Comparison of five rapid prototype techniques (SLS/FDM/DLP/ 3DP/polyjet). Innov Dev Virtual Phys Prot, 2012, 573-580

8 Anitha R, Arunachalam S, Radhakrishnan P. Critical parameters influencing the quality of prototypes in fused deposition modelling. $\mathrm{J}$ Mater Process Tech, 2001, 118: 385-388

9 Tay BY, Evans JRG, Edirisinghe MJ. Solid freeform fabrication of ceramics. Int Mater Rev, 2003, 48: 341-370

10 Hornbeck, Larry J. Digital light processing for high-brightness high-resolution applications. In: Proceedings of Electronic Imaging'97. International Society for Optics and Photonics, 1997

11 Utela B, Storti D, Anderson R, Ganter M. A review of process development steps for new material systems in three dimensional printing (3DP). J Manufact Proc, 2008, 10: 96-104

12 Mueller B, Kochan D. Laminated object manufacturing for rapid tooling and patternmaking in foundry industry. Comput Ind, 1999, 39: 
$47-53$

13 Singh R. Process capability study of polyjet printing for plastic components. J Mech Sci Technol, 2011, 25: 1011-1015

14 Jakab K, Norotte C, Marga F, Murphy K, Vunjak-Novakovic G, Forgacs G. Tissue engineering by self-assembly and bio-printing of living cells. Biofabrication, 2010, 2: 022001

15 Mironov V, Visconti RP, Kasyanov V, Forgacs G, Drake CJ, Markwald RR. Organ printing: tissue spheroids as building blocks. Biomaterials, 2009, 30: 2164-2174

16 Derby B. Printing and prototyping of tissues and scaffolds. Science, 2012, 338: 921-926

17 Ricci JL, Clark EA, Murriky A, Smay JE. Three-dimensional printing of bone repair and replacement materials: impact on craniofacial surgery. J Craniof Surg, 2012, 23: 304-308

18 Billiet T, Vandenhaute M, Schelfhout J, Van Vlierberghe S, Dubruel P. A review of trends and limitations in hydrogel-rapid prototyping for tissue engineering. Biomaterials, 2012, 33: 6020-6041

19 Vacanti CA. The history of tissue engineering. J Cell Mol Med, 2006, 10: $569-576$

20 Langer R, Vacanti JP. Tissue engineering. Science, 1993, 260: 920-926

21 Sekine H, Shimizu T, Yang J, Kobayashi E, Okano T. Pulsatile myocardial tubes fabricated with cell sheet engineering. Circulation, 2006, 114: I87-93

22 Macchiarini P, Jungebluth $\mathrm{P}$, Go T, Asnaghi MA, Rees LE, Cogan TA, Dodson A, Martorell J, Bellini S, Parnigotto PP, Dickinson SC, Hollander AP, Mantero S, Conconi MT, Birchall MA. Clinical transplantation of a tissue-engineered airway. Lancet, 2008, 372: 2023-2030

23 Delaere PR, Hermans R. Clinical transplantation of a tissue-engineered airway. Lancet, 2009, 373: 717-718; author reply 718-719

24 Atala A, Bauer SB, Soker S, Yoo JJ, Retik AB. Tissue-engineered autologous bladders for patients needing cystoplasty. Lancet, 2006, 367: 1241-1246

25 Hernon CA, Dawson RA, Freedlander E, Short R, Haddow DB, Brotherston M, MacNeil S. Clinical experience using cultured epithelial autografts leads to an alternative methodology for transferring skin cells from the laboratory to the patient. Regen Med, 2006, 1: 809-821

26 Haraguchi Y, Shimizu T, Sasagawa T, Sekine H, Sakaguchi K, Kikuchi T, Sekine W, Sekiya S, Yamato M, Umezu M, Okano T. Fabrication of functional three-dimensional tissues by stacking cell sheets in vitro. Nat Protoc, 2012, 7: 850-858

27 Stanton RA, Billmire DA. Skin resurfacing for the burned patient. Clin Plast Surg, 2002, 29: 29-51

28 Muraoka M, Shimizu T, Itoga K, Takahashi H, Okano T. Control of the formation of vascular networks in 3D tissue engineered constructs. Biomaterials, 2013, 34: 696-703

29 Groeber F, Holeiter M, Hampel M, Hinderer S, Schenke-Layland K. Skin tissue engineering - in vivo and in vitro applications. Adv Drug Deliv Rev, 2011, 63: 352-366

30 Shim JH, Kim JY, Park JK, Hahn SK, Rhie JW, Kang SW, Lee SH, Cho DW. Effect of thermal degradation of SFF-based PLGA scaffolds fabricated using a multi-head deposition system followed by change of cell growth rate. J Biomater Sci Polym Ed, 2010, 21: 1069-1080

31 Sekine H, Shimizu T, Sakaguchi K, Dobashi I, Wada M, Yamato M, Kobayashi E, Umezu M, Okano T. In vitro fabrication of functional three-dimensional tissues with perfusable blood vessels. Nat Commun, 2013, 4: 1399

32 Moon S, Kim YG, Dong L, Lombardi M, Haeggstrom E, Jensen RV, Hsiao LL, Demirci U. Drop-on-demand single cell isolation and total RNA analysis. PLoS One, 2011, 6: e17455

33 Sirringhaus H, Kawase T, Friend RH, Shimoda T, Inbasekaran M, Wu W, Woo EP. High-resolution inkjet printing of all-polymer transistor circuits. Science, 2000, 290: 2123-2126

34 Yeong WY, Chua CK, Leong KF, Chandrasekaran M, Lee MW. In- direct fabrication of collagen scaffold based on inkjet printing technique. Rapid Prot J, 2006, 12: 229-237

35 Weng B, Liu X, Shepherd R, Wallace GG. Inkjet printed polypyrrole/collagen scaffold: a combination of spatial control and electrical stimulation of PC12 cells. Syn Met, 2012, 162: 1375-1380

36 Nakamura M, Kobayashi A, Takagi F, Watanabe A, Hiruma Y, Ohuchi K, Iwasaki Y, Horie M, Morita I, Takatani S. Biocompatible inkjet printing technique for designed seeding of individual living cells. Tissue Eng, 2005, 11: 1658-1666

37 Li W, Sun W, Zhang Y, Wei W, Ambasudhan R, Xia P, Talantova M, Lin T, Kim J, Wang X, Kim WR, Lipton SA, Zhang K, Ding S. Rapid induction and long-term self-renewal of primitive neural precursors from human embryonic stem cells by small molecule inhibitors. Proc Natl Acad Sci USA, 2011, 108: 8299-8304

38 Fang Y, Frampton JP, Raghavan S, Sabahi-Kaviani R, Luker G, Deng CX, Takayama S. Rapid generation of multiplexed cell cocultures using acoustic droplet ejection followed by aqueous two-phase exclusion patterning. Tissue Eng Part C Methods, 2012, 18: 647-657

39 Demirci U, Montesano G. Single cell epitaxy by acoustic picolitre droplets. Lab Chip, 2007, 7: 1139-1145

40 Trappmann B, Chen CS. How cells sense extracellular matrix stiffness: a material's perspective. Curr Opin Biotech, 2013, 24: 948-953

41 Tschumperlin DJ, Liu F, Tager AM. Biomechanical regulation of mesenchymal cell function. Curr Opin Rheumatol, 2013, 25: 92-100

42 Lee $\mathrm{M}, \mathrm{Wu} \mathrm{BM}$. Recent advances in 3D printing of tissue engineering scaffolds. Methods Mol Biol, 2012, 868: 257-267

43 Matsumoto K, Ishiduka T, Yamada H, Yonehara Y, Arai Y, Honda K. Clinical use of three-dimensional models of the temporomandibular joint established by rapid prototyping based on cone-beam computed tomography imaging data. Oral Radiol, 2014, 30: 98-104

44 Kawaguchi N, Hatta K, Nakanishi T. 3D-culture system for heart regeneration and cardiac medicine. Biomed Res Int, 2013, 2013: 895967

45 Page H, Flood P, Reynaud EG. Three-dimensional tissue cultures: Current trends and beyond. Cell Tissue Res, 2013, 352: 123-131

46 Jakab K, Norotte C, Damon B, Marga F, Neagu A, Besch-Williford CL, Kachurin A, Church KH, Park H, Mironov V, Markwald R, Vunjak-Novakovic G, Forgacs G. Tissue engineering by self-assembly of cells printed into topologically defined structures. Tissue Eng Part A, 2008, 14: 413-421

47 Koch L, Kuhn S, Sorg H, Gruene M, Schlie S, Gaebel R, Polchow B, Reimers K, Stoelting S, Ma N, Vogt PM, Steinhoff G, Chichkov B. Laser printing of skin cells and human stem cells. Tissue Eng Part C Methods, 2010, 16: 847-854

48 Gruene M, Pflaum M, Hess C, Diamantouros S, Schlie S, Deiwick A, Koch L, Wilhelmi M, Jockenhoevel S, Haverich A, Chichkov B. Laser printing of three-dimensional multicellular arrays for studies of cell-cell and cell-environment interactions. Tissue Eng Part C Methods, 2011, 17: 973-982

49 Derby B. Bioprinting: Inkjet printing proteins and hybrid cell-containing materials and structures. J Mater Chem, 2008, 18: 5717-5721

50 De Cossart L, How T, Annis D. A two year study of the performance of a small diameter polyurethane (biomer) arterial prosthesis. J Cardiovasc Surg, 1989, 30: 388

51 Wu LQ, Payne GF. Biofabrication: using biological materials and biocatalysts to construct nanostructured assemblies. Trends Biotechnol, 2004, 22: 593-599

52 Mironov V, Trusk T, Kasyanov V, Little S, Swaja R, Markwald R. Biofabrication: a 21 st century manufacturing paradigm. Biofabrication, 2009, 1: 022001

53 Odde DJ, Renn MJ. Laser-guided direct writing for applications in biotechnology. Trends Biotechnol, 1999, 17: 385-389

54 Choi WS, Ha D, Park S, Kim T. Synthetic multicellular cell-to-cell communication in inkjet printed bacterial cell systems. Biomaterials, 2011, 32: 2500-2507

55 Guillemot F, Souquet A, Catros S, Guillotin B, Lopez J, Faucon M, Pippenger B, Bareille R, Rémy M, Bellance S. High-throughput laser 
printing of cells and biomaterials for tissue engineering. Acta Biomater, 2010, 6: 2494-2500

56 Pepper ME, Parzel CA, Burg T, Boland T, Burg KJL, Groff RE. Design and implementation of a two-dimensional inkjet bioprinter. In: Proceedings of Annual International Conference of the IEEE Engineering in Medicine and Biology Society, 2009. 6001-6005

57 Ringeisen BR, Kim H, Barron JA, Krizman DB, Chrisey DB, Jackman S, Auyeung R, Spargo BJ. Laser printing of pluripotent embryonal carcinoma cells. Tissue Eng, 2004, 10: 483-491

58 Barron J, Spargo B, Ringeisen B. Biological laser printing of three dimensional cellular structures. Appl Phys A, 2004, 79: 1027-1030

59 Barron JA, Krizman DB, Ringeisen BR. Laser printing of single cells: statistical analysis, cell viability, and stress. Ann Biomed Eng, 2005, 33: $121-130$

60 Guillotin B, Souquet A, Catros S, Duocastella M, Pippenger B, Bellance S, Bareille R, Rémy M, Bordenave L, Amédée J. Laser assisted bioprinting of engineered tissue with high cell density and microscale organization. Biomaterials, 2010, 31: 7250-7256

61 Wilson WC, Boland T. Cell and organ printing 1: Protein and cell printers. Anat Rec A Discov Mol Cell Evol Biol, 2003, 272: 491-496

62 Nishiyama Y, Nakamura M, Henmi C, Yamaguchi K, Mochizuki S, Nakagawa H, Takiura K. Development of a three-dimensional bioprinter: construction of cell supporting structures using hydrogel and state-of-the-art inkjet technology. J Biomech Eng, 2009, 131: 035001

63 Ahmed EM. Hydrogel: preparation, characterization, and applications. J Adv Res, 2015, 6: 105-121

64 Levett PA, Melchels FP, Schrobback K, Hutmacher DW, Malda J, Klein TJ. A biomimetic extracellular matrix for cartilage tissue engineering centered on photocurable gelatin, hyaluronic acid and chondroitin sulfate. Acta Biomater, 2014, 10: 214-223

65 Schuurman W, Levett PA, Pot MW, van Weeren PR, Dhert WJ, Hutmacher DW, Melchels FP, Klein TJ, Malda J. Gelatinmethacrylamide hydrogels as potential biomaterials for fabrication of tissue-engineered cartilage constructs. Macromol Biosci, 2013, 13: $551-561$

66 Billiet T, Gevaert E, De Schryver T, Cornelissen M, Dubruel P. The $3 \mathrm{D}$ printing of gelatin methacrylamide cell-laden tissue-engineered constructs with high cell viability. Biomaterials, 2014, 35: 49-62

67 Aguado BA, Mulyasasmita W, Su J, Lampe KJ, Heilshorn SC. Improving viability of stem cells during syringe needle flow through the design of hydrogel cell carriers. Tissue Eng Pt A, 2011, 18: 806-815

68 Kucukgul C, Ozler SB, Inci I, Karakas E, Irmak S, Gozuacik D, Taralp A, Koc B. 3D bioprinting of biomimetic aortic vascular constructs with self-supporting cells. Biotechnol Bioeng, 2015, 112: 811-821

69 Ratcliffe JH, Hunneyball IM, Smith A, Wilson CG, Davis SS. Preparation and evaluation of biodegradable polymeric systems for the intra-articular delivery of drugs. J Pharm Pharmacol, 1984, 36: $431-436$

70 Van Den Bulcke AI, Bogdanov B, De Rooze N, Schacht EH, Cornelissen $\mathrm{M}$, Berghmans $\mathrm{H}$. Structural and rheological properties of methacrylamide modified gelatin hydrogels. Biomacromolecules, 2000, 1: 31-38

71 Chung JHY, Naficy S, Yue ZL, Kapsa R, Quigley A, Moulton SE, Wallace GG. Bio-ink properties and printability for extrusion printing living cells. Biomater Sci, 2013, 1: 763-773

72 Detsch R, Sarker B, Grigore A, Boccaccini AR. Alginate and gelatine blending for bone cell printing and biofabrication. In: IASTED International Conference Biomedical Engineering Innsbruck. Austria: ACTA Press, 2013. 451-455

73 Zhang K, Chou CK, Xia X, Hung MC, Qin L. Block-cell-printing for live single-cell printing. Proc Natl Acad Sci USA, 2014, 111: 2948-2953

74 Yeong WY, Sudarmadji N, Yu HY, Chua CK, Leong KF, Venkatraman SS, Boey YC, Tan LP. Porous polycaprolactone scaffold for cardiac tissue engineering fabricated by selective laser sintering. Acta Biomater, 2010, 6: 2028-2034

75 Schantz JT, Brandwood A, Hutmacher DW, Khor HL, Bittner K. Osteogenic differentiation of mesenchymal progenitor cells in computer designed fibrin-polymer-ceramic scaffolds manufactured by fused deposition modeling. J Mater Sci Mater Med, 2005, 16: 807-819

76 Cao T, Ho KH, Teoh SH. Scaffold design and in vitro study of osteochondral coculture in a three-dimensional porous polycaprolactone scaffold fabricated by fused deposition modeling. Tissue Eng, 2003, 9 Suppl 1: S103-112

77 Chien KB, Makridakis E, Shah RN. Three-dimensional printing of soy protein scaffolds for tissue regeneration. Tissue Eng Part C Methods, 2013, 19: 417-426

78 Shim JH, Lee JS, Kim JY, Cho DW. Bioprinting of a mechanically enhanced three-dimensional dual cell-laden construct for osteochondral tissue engineering using a multi-head tissue/organ building system. J Micromech Microeng, 2012, 22: 085014

79 Lee W, Lee V, Polio S, Keegan P, Lee JH, Fischer K, Park JK, Yoo SS. On-demand three-dimensional freeform fabrication of multi-layered hydrogel scaffold with fluidic channels. Biotechnol Bioeng, 2010, 105: 1178-1186

80 Xu F, Sridharan B, Wang S, Gurkan UA, Syverud B, Demirci U. Embryonic stem cell bioprinting for uniform and controlled size embryoid body formation. Biomicrofluidics, 2011, 5: 022207

81 Gaebel R, Ma N, Liu J, Guan J, Koch L, Klopsch C, Gruene M, Toelk A, Wang W, Mark P. Patterning human stem cells and endothelial cells with laser printing for cardiac regeneration. Biomaterials, 2011, 32: 9218-9230

82 Billiet T, Gevaert E, De Schryver T, Cornelissen M, Dubruel P. The $3 \mathrm{D}$ printing of gelatin methacrylamide cell-laden tissue-engineered constructs with high cell viability. Biomaterials, 2014, 35: 49-62

83 Marcos R, Monteiro RA, Rocha E. Design-based stereological estimation of hepatocyte number, by combining the smooth optical fractionator and immunocytochemistry with anti-carcinoembryonic antigen polyclonal antibodies. Liver Int, 2006, 26: 116-124

84 Cui X, Breitenkamp K, Finn MG, Lotz M, D'Lima DD. Direct human cartilage repair using three-dimensional bioprinting technology. Tissue Eng Part A, 2012, 18: 1304-1312

85 Butscher A, Bohner M, Hofmann S, Gauckler L, Müller R. Structural and material approaches to bone tissue engineering in powder-based three-dimensional printing. Acta Biomater, 2011, 7: 907-920

86 Bartolo PJ, Almeida H, Laoui T. Rapid prototyping and manufacturing for tissue engineering scaffolds. Int J Comput Appl Technol, 2009, 36: 1-9

87 Seitz H, Rieder W, Irsen S, Leukers B, Tille C. Three-dimensional printing of porous ceramic scaffolds for bone tissue engineering. $\mathrm{J}$ Biomed Mater Res Part B Appl Biomater, 2005, 74: 782-788

88 Yang S, Leong KF, Du Z, Chua CK. The design of scaffolds for use in tissue engineering. Part II. Rapid prototyping techniques. Tissue Eng, 2002, 8: 1-11

89 Ang T, Sultana F, Hutmacher D, Wong YS, Fuh J, Mo X, Loh HT, Burdet E, Teoh SH. Fabrication of 3D chitosan-hydroxyapatite scaffolds using a robotic dispensing system. Mater Sci Eng C, 2002, 20: 35-42

90 Liu Tsang V, Bhatia SN. Three-dimensional tissue fabrication. Adv Drug Deliv Rev, 2004, 56: 1635-1647

91 Mironov V, Prestwich G, Forgacs G. Bioprinting living structures. J Mater Chem, 2007, 17: 2054-2060

92 Hassan W, Dong Y, Wang W. Encapsulation and 3D culture of human adipose-derived stem cells in an in-situ crosslinked hybrid hydrogel composed of peg-based hyperbranched copolymer and hyaluronic acid. Stem Cell Res Ther, 2013, 4: 32

93 Engler AJ, Sen S, Sweeney HL, Discher DE. Matrix elasticity directs stem cell lineage specification. Cell, 2006, 126: 677-689

94 Mei Y, Saha K, Bogatyrev SR, Yang J, Hook AL, Kalcioglu ZI, Cho SW, Mitalipova M, Pyzocha N, Rojas F, Van Vliet KJ, Davies MC, Alexander MR, Langer R, Jaenisch R, Anderson DG. Combinatorial development of biomaterials for clonal growth of human pluripotent stem cells. Nat Mater, 2010, 9: 768-778

95 Lee S, Kim J, Park TJ, Shin Y, Lee SY, Han YM, Kang S, Park HS. The effects of the physical properties of culture substrates on the 
growth and differentiation of human embryonic stem cells. Biomaterials, 2011, 32: 8816-8829

96 Pati F, Jang J, Ha DH, Won Kim S, Rhie JW, Shim JH, Kim DH, Cho DW. Printing three-dimensional tissue analogues with decellularized extracellular matrix bioink. Nat Commun, 2014, 5: 3935

97 Mondy WL, Cameron D, Timmermans J-P, De Clerck N, Sasov A, Casteleyn C, Piegl LA. Computer-aided design of microvasculature systems for use in vascular scaffold production. Biofabrication, 2009, 1: 035002
98 Duan B, Hockaday LA, Kang KH, Butcher JT. 3D bioprinting of heterogeneous aortic valve conduits with alginate/gelatin hydrogels. J Biomed Mater Res A, 2013, 101: 1255-1264

99 Murphy SV, Atala A. 3D bioprinting of tissues and organs. Nat Biotechnol, 2014, 32: 773-785

100 Chang CC, Boland ED, Williams SK, Hoying JB. Direct-write bioprinting three-dimensional biohybrid systems for future regenerative therapies. J Biomed Mater Res Part B Appl Biomater, 2011, 98: $160-170$

Open Access This article is distributed under the terms of the Creative Commons Attribution License which permits any use, distribution, and reproduction in any medium, provided the original author(s) and source are credited. 